\title{
Strategi Peningkatan Stakeholder Baru Organisasi Seni Pertunjukan
}

\author{
I Putu Ardiyasa \\ Sekolah Tinggi Agama Hindu Negeri (STAHN) Mpu Kuturan Singaraja; \\ Jalan Pulau Menjangan No. 27, Banyuning, Kecamatan Buleleng, \\ Kabupaten Buleleng - Bali 81119 \\ E-mail: tuardiyasa@gmail.com
}

\begin{abstract}
ABSTRAK
Dalam rangka penciptaan kualitas produk terbaik harus didukung oleh pemberdayaan modal manusia untuk merancang strategi ke depan, sehingga dapat memengaruhi stakeholder. Seni pertunjukan sebagai tindakan berbasis jasa yang sesungguhnya tidak akan terlepas dari keterlibatan stakeholder (penonton, sponsor, funding, pemerintah). Pengelola kesenian kurang memberdayakan dan mengembangkan potensi diri dalam mengaktualisasikan sekaligus mensosialisasikan keahliannya sesuai dengan perkembangan zaman. Hal ini berdampak pada kualitas produk yang dapat dimengerti, diterima, dan membuat tertarik para stakeholder. Penelitian ini membahas tentang pemberdayaan sumber daya manusia dalam rangka meningkatkan stakeholder baru. Penelitian ini menemukan tawaran strategi pengelola pertunjukan dalam meningkatkan penonton baru, kerja sama sponsorship, dan para pemberi dana pemerintah atau swasta. Data dikumpulkan dengan observasi lapangan dan wawancara pada beberapa ahli yang berpengalaman dalam menjalankan sebuah organisasi. Hasilnya menunjukkan bahwa kualitas karya adalah modal utama dalam menjaga kepercayaan stakeholder. Selain itu, jaringan personal, sharing knowledge, program workshop, event festival, pemberdayaan media sosial adalah upaya yang dilakukan oleh organisasi dalam meningkatkan stakeholder baru.
\end{abstract}

Kata kunci: stakeholder baru, organisasi seni pertunjukan

\section{New Stakeholder Improvement StrategyPerforming Arts Organization} ABSTRACT

When we talk about arts, especially performance art as a service-based act, it cannot be inseparable from the involvement of stakeholders (audience, sponsors, funding, government). The arts manager is less empowering and developing his potential in actualizing and at the same time socializing his skills in accordance with the times. It has an impact on the quality of the product that can be understood, accepted and attracted by the stakeholders. In order to create the best product quality, it must be supported by empowering human capital to design strategies in the future, so it can influence stakeholders. This study addresses these problems with the aim of obtaining offers from show management strategies to increase new audiences, sponsorship cooperation and public or private funders. Data is collected through field observations and interviews with several experts who are experienced in running an organization. The results show that the quality of works is the important thing must be considered in maintaining stakeholder confidence. In addition, Personal Networks, Knowledge Sharing, Workshop Programs, Event Festivals, Social Media Empowerment are efforts made by organizations to increase new stakeholders.

Keywords: new stakeholder, performance art organization 


\section{PENDAHULUAN}

Kehadiran seni pertunjukan di ruang publik tidak terlepas dari keterlibatan kelompok-kelompok dan/atau individu-individu, baik secara langsung dan tidak langsung, berkontribusi terhadap perkembangan organisasi. Freeman mengidentifikasi stakeholder sebagai kelompok-kelompok atau setiap individu yang dapat memengaruhi pencapaian tujuan organisasi, atau dipengaruhi oleh pencapaian tujuan organisasi (Freeman, 2010: 5). Kelompok atau individu yang dimaksud dibagi menjadi dua yaitu stakeholder internal (seniman) dan stakeholder eksternal (penonton, additional crew, donatur, masyarakat, dan pemerintah). (Clarkson, 1995: 106) menyebutkan, bahwa stakeholder adalah orang-orang yang memengaruhi atau dipengaruhi oleh organisasi yang tidak secara langsung terlibat di dalam proses produksi. Jika tanpa partisipasi dari mereka, organisasi tidak dapat menjaga keberlangsungan hidupnya. Selain itu, Freeman (2010: 10) menambahkan bahwa orang-orang yang terlibat dan bertanggung jawab dalam proses penciptaan nilai organisasi justru kelompokkelompok dan individu yang dapat memengaruhi atau dipengaruhi oleh tindakan mereka, yaitu para stakeholder.

Peran posisi stakeholder dalam organisasi tidak berarti bahwa kelompokkelompok ini duduk di papan struktur untuk mengatur organisasi, juga tidak berarti bahwa mereka tidak memiliki hak. Kehadiran stakeholder berdampak positif pada upaya organisasi untuk berbuat yang lebih baik dan membuat strategi tentang bagaimana hal itu bisa dikerjakan. Deegan (2006: 7) melihat bahwa organisasi akan cenderung memenuhi harapan para pemangku kepentingan karena mereka memiliki hak-hak untuk mendapatkan keadilan dan untuk dilayani. Dengan demikian, perlu adanya perilaku organisasi yang dapat memengaruhi keterlibatan stakeholder secara berkelanjutan, merawat keterlibatannya, bahkan meningkatkan pertumbuhan stakeholder (eksternal) baru.

Seiring banyaknya pertumbuhan organisasi budaya di Indonesia, semakin banyak pula produk seni yang dihadirkan, namun tidak banyak pula yang mampu menjaga keberlanjutannya (terus berkarya). Banyak organisasi budaya yang bangkrut, dengan berbagai alasan, termasuk tidak memberdayakan sumber daya manusia dalam membangun relasi dan kepercayaan stakeholder. Hasilnya, beberapa kelompok seni mengalami penurunan produktivitas dan sulit mencari generasi penerus. Banyak organisasi seni pertunjukan yang masih mencari pola atau cara mempertahankan keberlanjutan kelompok seninya. Namun, di sisi lain ada beberapa organisasi seni pertunjukan juga mampu menjaga eksistensinya secara terintegritas, memiliki jaringan luas, serta loyalitas anggota yang tinggi, salah satunya Papermoon Puppet Theatre di Yogyakarta (PPT).

Ketika mendalami kegiatan PPT, beberapa pertanyan muncul, mengapa PPT bisa eksis di dalam dan luar negeri, sedangkan banyak komunitas lain dengan 
kualitas teknik dan artistik yang tidak kalah tinggi, namun tidak mampu bertahan secara berkelanjutan? Bagaimana peran stakeholder terhadap keberlanjutan PPT? Berdasarkan hal tersebut peneliti menemukan celah pada pemberdayaan stakeholder sebagai aset seni pertunjukan yang menjadi perhatian untuk membuktikan bahwa permasalahan di atas dipengaruhi oleh lemahnya perhatian terhadap stakeholder. Dengan demikian, penelitian ini akan mengkaji permasalahan penelitian dengan pendekatan studi kasus, yaitu peningkatan stakeholder dalam pembangunan relasi PPT dengan stakeholder internal dan eksternal, sehingga memperoleh profitabilitas (pengetahuan, jaringan, keharmonisan anggota, dan finansial) untuk kembali diberdayakan dalam proses penciptaan nilai produk, organisasi, dan relasi yang berkelanjutan.

\section{Kajian Teori Stakeholder}

Teori Stakeholder berkembang sejak tiga puluh tahun yang lalu. Kemunculannya diidentifikasi Freeman (2010: 3-4) sebagai respons terhadap masalah penciptaan nilai serta munculnya kekuasaan kapital etis dan pola pikir manajerial. Lebih jauh dijelaskan bahwa teori stakeholder mampu mengadopsi hubungan antara bisnis dengan kelompok dan/atau individu yang saling memengaruhi sehingga masalah tersebut dapat ditangani. Dengan kata lain, munculnya masalah-masalah tersebut dapat diselesaikan apabila relasi antara manajer dan para pemangku kepentingan terjalin baik dan terbuka. Manajemen organisasi melakukan aktivitas yang dianggap penting oleh stakeholder dan melaporkan kembali aktivitas-aktivitas tersebut kepada stakeholder. Teori ini menyatakan bahwa seluruh stakeholder memiliki hak untuk disediakan informasi tentang bagaimana aktivitas organisasi memengaruhi mereka. Selain itu, organisasi akan secara sukarela mengungkapkan informasi tentang kinerja lingkungan, sosial, dan intelektual mereka untuk memenuhi ekspektasi sesungguhnya yang diakui (Deegan, 2006: 295).

Dalam konteks penjelasan konsep Modal Intelektual (MI), peneliti meminjam teori Deegan yang memandang teori stakeholder dari bidang etika (moral) dan bidang manajerial. (1) Bidang etika berargumen bahwa seluruh stakeholder memiliki hak untuk diberikan informasi dan manajer harus mengelola organisasi untuk keuntungan seluruh stakeholder. Ketika manajer mampu mengelola organisasi secara maksimal, khususnya dalam upaya penciptaan nilai bagi perusahaan, maka itu artinya manajer telah memenuhi aspek etika dari teori ini. (2) Bidang manajerial dari teori ini berpendapat bahwa kekuatan stakeholder untuk memengaruhi manajemen dalam mengelola sumber daya yang dibutuhkan dan pengambilan keputusan. Perspektif manajerial ini mencoba untuk menjelaskan kapan pengelola organisasi akan cenderung memenuhi harapan para pemangku kepentingan (Deegan, 2006: 294). 
Terkait penciptaan nilai, Freeman (2010: 24) menambahkan penciptaan nilai bagi stakeholder cukup sederhana. Bisnis dapat dipahami sebagai perangkat hubungan antara kelompok-kelompok yang memiliki kepentingan dalam kegiatan yang membentuk bisnis. Dalam hal ini proses interaksi seniman, tim teknisi, audiens, pemodal, pemilik, dan masyarakat yang menjadi relasi untuk menciptakan nilai tambah organisasi.

Untuk memahami kegiatan usaha tersebut harus dipandang dari kedua bidang, yaitu bidang etika (mengetahui bagaimana hubungan ini bekerja) maupun bidang manajerial (bagaimana pihak eksekutif mengelola hubungan ini). Teori ini dapat diuji dengan menerapkan analisis isi (content analysis) dan mengonfirmasi laporan tahunan perusahaan (Guthrie, et al., 2006: 256). Laporan tahunan adalah cara yang paling efisien untuk sebuah organisasi untuk berkomunikasi dengan kelompok-kelompok pemangku kepentingan. Dalam hal ini laporan tahunan yang dimaksud adalah seperangkat dokumen tertulis, baik dalam bentuk cetakan dan media online, serta wujud apresiasi pada stakeholder. Sebuah analisis isi dari pengungkapan MI dapat digunakan untuk menentukan komunikasi sudah terjadi atau belum terjadi. Perusahaan menanggapi harapan pemangku kepentingan yang nyata atau dirasakan dengan menawarkan kesukarelaan dan keadilan dalam memberikan informasi atau tidak.

\section{METODE PENELITIAN}

Penelitian ini dilakukan dengan metode kualitatif untuk mengeksplorasi dan memahami makna yang oleh sejumlah individu atau sekelompok orang dianggap berasal dari masalah sosial atau kemanusiaan (Creswell, 2016: 4-5). Makna yang dipahami pada penelitian ini adalah pemahaman terhadap permasalahan pembangunan relasi dan hubungannya dengan modal intelektual suatu kelompok seni. Berdasarkan topik dan variabel penelitian, objek penelitian ini dibagi menjadi dua yaitu, objek formal dan material.

Objek formal adalah peningkatan stakeholder baru, sedangkan objek materialnya adalah Papermoon Puppet Theater. Pemilihannya ditentukan berdasarkan pertimbangan isu penelitian yang telah diuraikan pada pendahuluan. Pemilihan narasumber ditentukan berdasarkan (1) Pengetahuan yang jelas tentang PPT (narasumber kunci); (2) Keterlibatan aktif dalam seluruh kegiatan PPT (narasumber penguat); (3) Seseorang yang berperan penting dalam membangun dan memotivasi PPT, baik membangun internal dan eksternal PPT (narsumber ahli). Data dikumpulkan dengan metode observasi lapangan, wawancara, dan studi pustaka.

Variabel yang terdapat pada penelitian ini adalah variabel modal intelektual yang membangun hubungan interpersonal organisasi. Komponen atau 
variabel yang dimaksud yaitu, modal relasi $(R C)$ (Bontis, 2000: 6-8). Selain itu, variabel modal manusia $(H C)$ dan modal struktur $(S C)$ dilacak untuk mengetahui peran relasi dalam membangun modal-modal tersebut. Pelacakan hubungan timbal balik pada setiap indicator dilakukan untuk mengetahui bagaimana proses terbangunnya relasi, baik relasi internal maupun relasi eksternal organisasi seni pertunjukan dalam meningkatkan stakeholder barunya.

\section{HASIL DAN PEMBAHASAN}

\section{Peningkatan Stakeholder Baru}

Peningkatan stakeholder baru dilakukan melalui strategi-strategi yang sederhana, seperti penerapan konsep berbagi, pengenalan (workshop), dan konsep belajar. Melalui konsep berbagi, penonton diajak ke atas panggung mencoba memainkan boneka, melihat setting panggung dari jarak dekat, dan berdialog ringan dengan para pemain PPT. Namun, penonton baru tidak secara langsung akan datang, melainkan melalui beberapa tahapan. Ketika tahap ini selesai, akan muncul citra positif (reputasi) organisasi dan penonton merasa puas dan nyaman dengan pengalaman yang diperoleh. Seperti pada kutipan pernyataan wawancara di bawah ini.

...Kita seneng sharing, semua orang disuruh nyobak boneka, suruh ngeliat set-nya, suruh ngeliat dapur behind the scene kayak apa itu karena itu, karena kita-kita seneng sharing. Seperti aku bilang di awal, pendidikan itu ada dari awal darah papaermoon gitu loh. Sharing knowledge itu dibikin sejak awal Papermoon ada... (Wawancara Sulistyani, 13 April 2017)

Melalui konsep ini sesungguhnya tidak akan terjadi peningkatan penonton secara langsung, melainkan melalui beberapa tahapan. Tahapan yang dimaksud adalah ketika penonton mendapat pengalaman terhadap peristiwa di panggung, kemudian munculnya reputasi organisasi dan kepercayaan penonton, maka tahap selanjutnya penonton berpeluang besar untuk menyampaikan peristiwa yang dialami kepada keluarga, kerabat, dan orang terdekat lainnya. Sulistyani menambahkan bahwa PPT gemar berbagi pengetahuan (sharing knowledge) yang sudah muncul sejak awal PPT berdiri dan dilakukan sampai sekarang. Jadi tidak salah jika PPT mampu menjalin hubungan timbal balik yang saling menguntungkan dengan para stakeholder. 


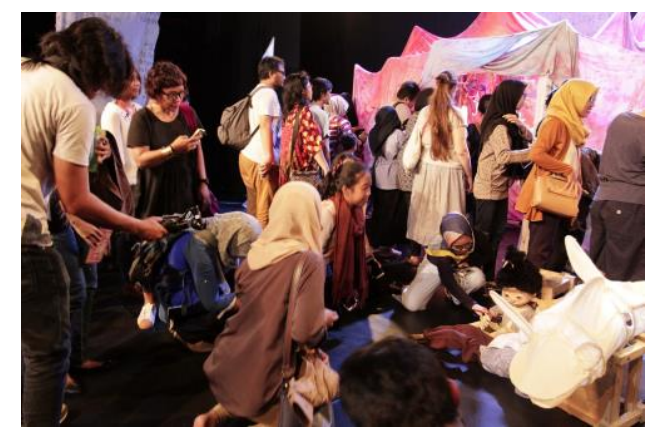

Gambar 1. Kesempatan penonton naik ke panggung pada pertunjukan PPT Sumber: Dokumentasi Peneliti, 2016

\section{Program Workshop}

Peningkatan stakeholder baru juga dilakukan melalui program workshop. Peserta workshop yang datang mendapatkan pengetahuan cara membuat boneka serta memainkan bonekanya. PPT selalu membatasi peserta workshop antara lima belas hingga dua puluh lima peserta untuk menjaga efektivitas pemberian materi. Dengan adanya pembatasan jumlah itu, para peserta workshop lebih leluasa bergerak dan lebih mudah untuk mencerna materi yang diberikan. Sebagai anggota PPT yang masuk melalui jalur audisi, Jati merasakan hal yang serupa bahwa melalui workshop itu mampu meyakinkan dirinya tentang keberadaan PPT (dalam wawancara 13 April 2017, di Rumah PPT).

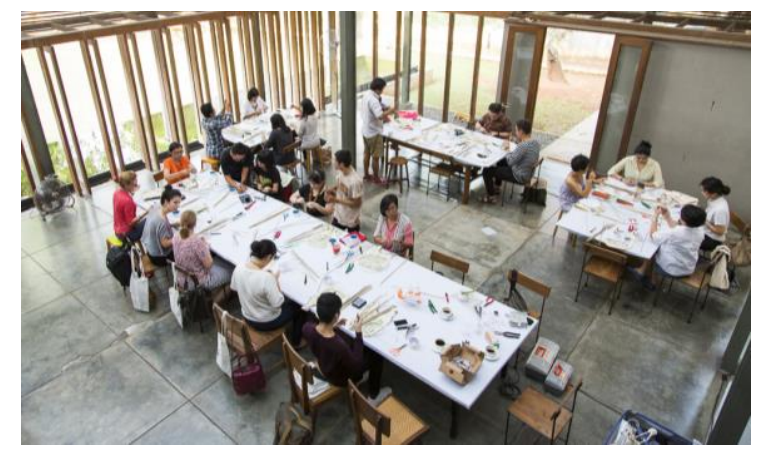

Gambar 2. Workshop Pembuatan Boneka PPT di Manual Jakarta Sumber: Dokumentasi Liandro Siringoringo,2016

Workshop memberikan dampak besar bagi calon-calon stakeholder PPT untuk terlibat, baik sebagai anggota maupun audiens, bahkan workshop menjadi media seleksi yang relevan dalam menyaring komitmen calon stakeholder. Seperti kutipan wawancara di bawah ini.

...kalau audisi itu mereka memilih datang, bukan kita yang memilih mereka. Mereka datang, jadi dengan kesadaran penuh bahwa mereka datang, membuka diri untuk berproses, bukan kita, misalnya "di kamu lagi slow gak?” main yuk...(Wawancara Efendi, 30 Maret 2017). 
Workshop yang dihadirkan berfungsi ganda, yaitu (1) menghadirkan peserta baru yang belum pernah terlibat pada peristiwa pertunjukan PPT serta; (2) mendapatkan anggota baru. Peserta yang datang adalah orang-orang yang memilih berdasarkan keinginan sendiri, bukan ditentukan oleh PPT. Jadi, setiap orang datang dengan kesadaran penuh untuk membuka diri dalam berproses, sehingga salah satu dari mereka yang terlibat akan dipilih menjadi anggota, sedangkan peserta lain berpeluang menjadi penonton PPT. Seperti pada pernyataan wawancara berikut ini.

...terus kita kan ya ngerasa "sekalian aja kita nyebarin virus teater boneka dari workshop" kan gitu. Artinya gak cuman satu orang doang yang sempet ngalamin proses cara PPT bikin karya ada 9 orang lain yang terlibat yang bisa mengalami dan kita gak pernah tau efeknya bakal jadi apa. Siapa tau selesai-selesai mereka bikin puppet teater sendiri gitu loh. Kalau mereka malah bikin puppet theater-nya sendiri kita malah seneng ada temennya (wawancara Sulistyani, 13 April 2017).

Melalui workshop ini PPT mendapat stakeholder internal dan eksternal yang sangat berintegritas dan loyalitas tinggi sehingga menjadikan organisasi memiliki pondasi kerja sama dan kekeluargaan yang kuat. Kepemilikan aset ini adalah kewajiban organisasi untuk menjaga keberlangsungan hidupnya.

\section{Pemberdayaan Media Sosial}

Peran media sosial PPT di kalangan masyarakat digital ini berperan penting sebagai sarana menebar gaung. Beberapa narasumber penonton mengatakan hal yang senada, bahwa sebelum menjadi penonton setia, mereka mengikuti akun media sosial (Instagram, Facebook, dan Blogspot) PPT untuk mendapatkan informasi terkait proses produksi, lokasi pertunjukan, penjualan tiket, program-program, termasuk hal-hal yang bersifat historis (sejarah, karyakarya terdahulu). Bahkan sampai sekarang media sosial menjadi ruang komunikasi PPT dengan penonton untuk menyebarkan informasi. Seperti kutipan pernyataan wawancara narasumber berikut ini.

...sosial medianya itu sebagai eeee kalau aku bisa bilang apa ya, kalau aku sih sebagai penebar gaung ya, kalau ada ada gong terus dikasi corong, kemudian bwaaanggg [meniru suara gong] nah itu tuh dia posting langsung PPT blablabla, kita repost untuk menambah gaung lagi [...] Jadi apa yang orang bilang sama kita, sukanya kita repost, atau kita rumahkan di blog-nya Papermoon disebar lagi. Jadi itu hubungannya sama merawat audiens... (wawancara Sulistyani, 13 April 2017)

Peran penting media sosial yang diberdayakan PPT dapat dilihat melalui pernyataan Gone (pada wawancara 5 Mei 2017, di Milas Coffee) yang 
menyatakan "bahwa perkenalan dengan PPT berawal dari media sosial. Media sosial membantunya menjelaskan keberadaan PPT dan menjadi media penghubungnya dengan pemilik PPT. Gone merasa bangga ketika membagikan gambar di akun media sosialnya itu kemudian direpost oleh PPT". Proses ini sederhana tapi mendapat respons penting dari stakeholder. Kegiatan mengirim ulang dan merumahkan tulisan orang lain di blog PPT dikatakan Efendi sebagai upaya merawat audiens. Selain itu, Iwan menegaskan di era digital kita sedang berlomba membuat publikasi, poster sudah tidak efektif, mau bertemu orang secara langusng terbentur dengan kesibukan. Oleh sebab itu, internet dapat dimanfaatkan secara efektif dan optimal (wawancara Efendi, 31 April 2017 di kediamannya).

\section{Event Festival}

PPT memiliki festival dua tahunan berskala internasional, yaitu Pesta Boneka. Pesta Boneka banyak mendatangkan seniman-seniman wayang, teater boneka dari berbagai negara dan berbagai daerah di Indonesia, mereka mempertunjukkan karyanya dan membawa penontonnya. Setiap orang yang hadir di Pesta Boneka secara langsung dapat menyaksikan berbagai jenis pertunjukan teater boneka termasuk mengetahui keberadaan PPT. Sulistyani menyatakan bahwa "Pesta Boneka diadakan agar PPT menjadi penonton di antara penontonpenonton lain yang datang melihat karya pertunjukan seniman-seniman mancanegara" (dalam wawancara 13 April 2017 di Rumah Papermoon). Kehadiran Pesta Boneka tidak dapat dilepaskan dari kemampuan PPT dalam menjalin hubungan timbal balik. Seperti pada kutipan wawancara berikut ini.

...Pesta Boneka menjadi eee satu-satunya festival teater boneka di Asia Tenggara[...] Papermoon dan Ria punya spirit dan personal connection antara PPT dengan para seniman sehingga bisa mendatangkan banyak seniman luar negeri[...] di Pesta Boneka, ibuibu dan kakek tua di Desa Kepek itu dengan enaknya nyantap makanan, ngomentarin bahkan bisa berinteraksi, hampir gak ada batas...(Wawancara Wijayanti, 6 Mei 2017)
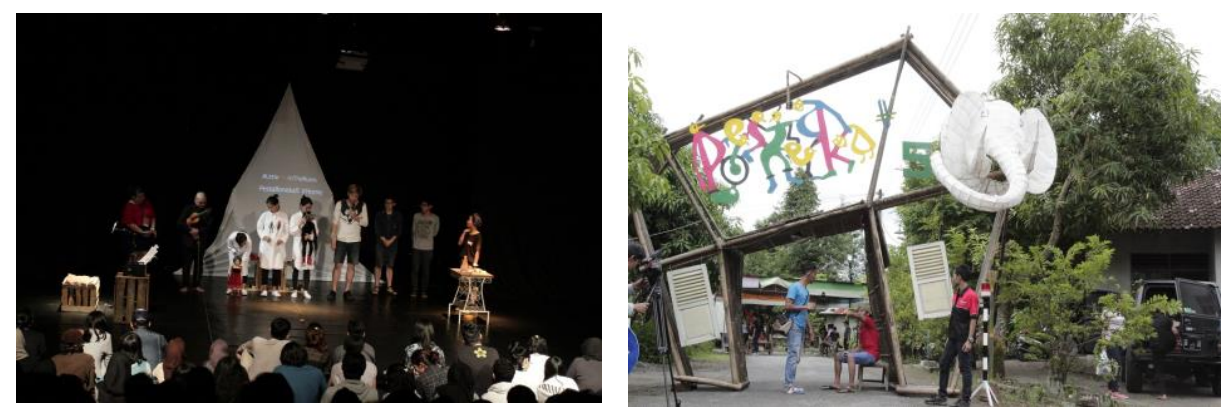

Gambar 3. Seniman yang pernah bertemu PPT dan tampil di Pesta Boneka. Sumber: Dokumentasi Peneliti, 2016 
Kutipan tersebut menunjukkan bahwa Pesta Boneka juga menjadi ruang interaksi PPT dengan orang-orang (seniman dan audiens) baru. Interaksi ini akan memunculkan stakeholder baru. Dalam rangka mengenalkan teater boneka kepada masyarakat, Pesta Boneka diadakan di tengah perkampungan warga. Warga desa dilibatkan, baik sebagai panitia, peserta workshop, penonton, dan pedagang di bazar. Ketika mendapatkan respons positif dari masyarakat maka, masyarakat itulah yang nantinya akan menjadi penonton-penonton baru PPT. Respons positif tersebut akan menjadi penggerak pada peningkatan penonton baru melalui penyebaran informasi secara verbal dan visual (melalui media online).

\section{Jaringan Personal (personal connection)}

Jaringan personal (personal connection) menjadi pokok penting dalam kasus meningkatkan stakeholder baru. PPT mampu membangun hubungan timbal balik dengan seniman-seniman luar negeri yang pernah dijumpai ketika pentas di luar negeri, sehingga seniman-seniman yang hadir pada Pesta Boneka adalah seniman yang dikenal oleh PPT. Hubungan ini menjadi aset penting menurut Wijayanti (dalam wawancara 13 April 2017 di Jogja Contemporary), karena "pertemanan itu pasti akan memunculkan peluang-peluang baru, salah satunya kehadiran secara sukarela seniman-seniman di Pesta Boneka, bahkan Efendi menekankan (dalam wawancara 31 Maret 2017) dengan publik itulah kita bisa meraih apapun. Artinya bahwa, publik yang dibangun oleh PPT berdasarkan jaringan personal mampu menghadirkan aset-aset baru, baik aset ruang sosial, penonton, seniman, media partner, bahkan donatur. Indikator-indikator peningkatan stakeholder baru dapat terlihat pada tabel 1.

\section{Tabel 1. Model Peningkatan Stakeholder Baru PPT}

\begin{tabular}{ll}
\hline Variabel & Indikator \\
\hline Reputasi Organisasi & $\bullet$ Jaringan Personal (personal connection) \\
& $\bullet$ Sharing knowledge \\
& $\bullet$ Program Workshop \\
& $\bullet$ Event Festival \\
& $\bullet$ Pemberdayaan Media Sosial \\
\hline
\end{tabular}

\section{KESIMPULAN}

Stakeholder organsasi terdiri dari penonton, pemberi dana (pemerintah dan swasta), dan seniman yang memiliki komitmen, budaya kerja, dan strategi pengembangan organisasi kuat. Sistem organisasi (tolok ukur, kepemimpinan, dan keterlibatan stakeholder, evaluasi, dan fokus stakeholder) pada aspek etika dan manajerial. Organisasi menjadi ruang belajar, ruang komunikasi, dan ruang 
produksi seni berbasis jasa, serta pemberdayaan stakeholder sebagai aset atau modal utama. Keberlanjutan organisasi menjaga integritas anggota dan produktivitas penciptaan karya sejak tahun 2006 sampai sekarang menjadi bukti peran serta modal-modal yang diberdayakan dan dirawat. Pemberdayaan yang dilakukan, meliputi (1) tour and research; (2) residensi dan kolaborasi; (3) penyelenggaraan festival; (4) workshop. Dalam rangka merawat stakeholder, organisasi melakukan: (1) sharing knowledge; (2) pemberdayaan media sosial; dan (3) jaringan personal untuk menjalin relasi yang berkelanjutan.

\section{KEPUSTAKAAN}

Ardiyasa, I. P. (2016). Kepercayaan Interpersonal: Keberlanjutan Pengelolaan Organisasi Papermoon Puppet Theatre. Jurnal Tata Kelola Seni, 2(1), 3138. https://doi.org/https://doi.org/10.24821/jtks.v2i1.1812

Ardiyasa, I. P. (2020). Pembangun dan Pelibatan Keluarga dalam Siklus Hidup Seni Pertunjukan Pariwisata pada Teater Bali Agung Taman Safari and Marine Park. Cultoure: Jurnal Ilmiah Pariwisata Budaya Hindu, 1(1), 6372.

Bontis, N. W. C. C. K. and S. R. (2000). Intellectual Capital and Business Performance in Malaysian Industries. Journal of Intellectual Capital, 1(1), 85-100. https://doi.org/https://doi.org/10.1108/14691930010324188

Clarkson, M. B. E. (1995). A stakeholder framework for analyzing and evaluating corporate social performance. The Academy of Management Review, 20(1), 92-117. https://doi.org/https://doi.org/10.2307/258888

Creswell, J. W. (2016). Research Design: Pendekatan Metode Kualitatif, Kuantitatif dan Campuran (4th ed.). Yogyakarta: Pustaka Pelajar.

Deegan, C. (2006). Financial Accounting Theory. Australia: McGraw-Hill Global Education Holding.

Freeman, R. E. (2010). Stakeholder Theory: The State of the Art. New York: Cambridge University Press.

Guthrie, J.; R. P. ; F. R. (2006). The voluntary reporting of intellectual capital: Comparing evidence from Hong Kong and Australia. Journal of Intellectual Capital, 7(2), 254-271. https://doi.org/10.1108/14691930610661890

Guthrie, J. (2001). The management, measurement and the reporting of intellectual capital. Journal of Intellectual Capital, 2(1), 27-41. https://doi.org/10.1108/14691930110380473

Hadi, S. Y. (2012). Seni Pertunjukan dan Masyarakat Penonton. Yogyakarta: BP ISI Yogyakarta.

Keiser, M. M. \& B. E. E. (2013). The Cycle: A Practical Approach to Managing Arts Organization. Waltham/Boston, Massachusetts: Brandeis University. 